\title{
Learning Model for Exposition Text Writing on Learners in Visual, Auditory and Kinesthetic Learning styles
}

\author{
Ida Zulaeha1, Sofiah ${ }^{2}$, Rahayu Pristiwati ${ }^{3}$, Tommi Yuniawan ${ }^{4}$ \\ ${ }_{1,3,4}$ Universitas Negeri Semarang, Indonesia \\ ${ }^{2}$ Madrasah Aliyah Negeri 1 Kudus, Indonesia \\ Corresponding email: idazulaeha@mail.unnes.ac.id
}

\begin{abstract}
The purpose of this study is to analyze the effectiveness of learning writing skills of exposition text containing conservation values with cooperative integrated reading and composition models based on learning styles of student's X class. Learning styles affect the effectiveness of learning putting ideas or opinions in a paper that provides information, knowledge, usefulness benefits to its readers including thesis, argumentation, and reaffirmation. The research was conducted by using quasi-experimental factorial design on learners Madrasah Aliyah. The learning process is carried out in accordance with the syntax of teams, placement test, student creative, team study, team scorer and team recognition, teaching group, facts test, and whole-class units. As a result, learning to write expository text with CIRC models based on learning style of learners is more effective on learners in visual style rather than auditory and kinesthetic. The effectiveness of learning occurs because the behavior of learners shows a positive change, namely more cooperation, appreciate the opinions of others, and the development of science in the academic field.
\end{abstract}

Keywords: exsposition texts, conservation values, CIRC models, learning styles

\section{Introduction}

In functional flow, language functions as a means of forming human thinking. The use of language is the process of selecting linguistic forms in expressing meaning. Writing is an activity of expressing ideas, goals, and intentions that use linguistic forms in expressing certain imaginative and real meanings (Zulaeha, 2016). Learning to write exposition text in the 2013 High School (SMA) or Madrasah Aliyah (MA) curriculum undergoes fundamental changes following functional flow, namely text-based language learning. The goal is to bring students according to their mental development and solve real-life problems with critical thinking.

Environmental crisis, lack of carrying capacity, and deterioration of the trust and identity of a nation (Unnes Conservation Development Team, 2014) become important issues or issues that become the topic of exposition texts written by students.

Nevertheless, research (Zulaeha, 2017) reports that the writing skills of students in SMA / MA still need to be optimized. They need to be taught to skillfully write exposition texts (Finoza, 2009; Kosasih, 2012) that integrate conservation values, namely values to save, protect, and preserve the surrounding environment as taught by the ancestors of the Indonesian people as an attempt to awaken future generations.
Learning to write exposition text with conservation values is more appropriate with the Cooperative Integrated Reading and Composition (CIRC) model. In this learning model reading and writing skills in heterogeneous groups are more concerned. Those who have auditory, visual, and kinesthetic learning styles are individually accustomed to being active, working together, and sharing information obtained from reading (Slavin, 2010) in writing exposition (Mahsun, 2014) texts containing conservation values.

Innovative educators need a learning model of exposition text writing that familiarizes heterogeneous students to realize the importance of preserving and saving the environment and culture that has been tested. The analysis of the effectiveness of the learning of exposition text writing skills containing conservation values with the integrated reading and composition cooperative model based on the learning styles of students is the purpose of this study.

This learning to write exposition text with a proven model is a learning strategy that can be used by educators to familiarize students with awareness and care for environmental and cultural preservation expressed in the exposition text produced with the right and creative structure and language. 


\section{Methods}

This study was carried out using a factorial quasi-experimental research design that takes into account the possibility of a moderator variable that affects the treatment (independent variables) of the results (dependent variable) (Sugiyono, 2011). In this study the visual learning style, the auditory characteristics of class X students that influence dependent variables are considered. Determination of the sample is done by purposive sampling to determine certain considerations and needs, namely the effect of treatment on exposition text writing skills of State and Private High School/Madrasah students (Arikunto, 2010).

The sample of this research is exposition text writing skills containing conservation values for students of Xth grade students of MAN 1 Kudus and Xth grade students of MA Al-Irsyad Gajah Demak 2016/2017 Academic Year by considering: (1) having a minimum standard of completeness criteria on Indonesian language lessons 75, (2) madrassas accredited A, (3) learning facilities and infrastructure available, and (4) students have heterogeneous abilities.

The variables of this study are two independent variables, one dependent variable, and two intermediate variables or attributes. The first independent variable (X1) is the CIRC model of the second independent variable (X2) is the TTW model. The dependent variable (Y1) is the ability of students to write exposition texts containing conservation values. The moderator research variables are visual, auditory, and kinesthetic learning styles. The assessment instrument of exposition text writing skills contains conservation values in the form of an assessment rubric, covering aspects of content, organization, diction, language use, and mechanics.

Data collection was carried out using performance test techniques, questionnaires, and observations. The data analysis technique used was descriptive comparative, namely comparing the results of the initial and final ability tests. Based on the data obtained, it was analyzed whether the average score of the experimental group one with the experimental group two differed significantly or not. Statistical analysis conducted in this study was carried out with the help of the Statistical Package for Social Sciences (SPSS) 16.0 for Windows. Rejection criteria or significance level at 5\% level means that $95 \%$ confidence level is if Fcount> Ftable then $\mathrm{H} 1$ is accepted $\mathrm{H} 0$ is rejected, but if $\mathrm{t}$ count <ttable then $\mathrm{H} 1$ is rejected and $\mathrm{HO}$ is accepted.

\section{Results and Discussion}

The effectiveness of learning to write conservation mutant exposition texts with the CIRC model can be seen from the elements of the CIRC model during learning and seen from the learning outcomes of students. The application of the CIRC model includes the application of model principles, syntaxmatics, reaction systems, support systems, as well as instructional impacts and accompanying effects of the CIRC model. Learning outcomes of students can be seen from the achievement of minimum completeness criteria on the basic competencies of writing exposition texts in writing. The effectiveness of learning to write exposition text with the CIRC model is supported by the learning styles of students, so that learning styles influence the learning process and results of students.

The interaction between students and teachers in learning has a high meaning so that students are skilled in writing exposition texts according to their respective tasks. The effectiveness of learning exposition text writing containing conservation values with the CIRC model is known through the stages or syntactic of the CIRC model that is carried out thoroughly and thoroughly (Zulaeha, 2017; Hidayati \& Zulaeha, 2018). The syntaxmatics of the CIRC model include team stages, placement test, student creative, team time an recognition, teaching group, fact test, whole class units.

At the first meeting, in groups the students read and examine the exposition text that was displayed by the teacher through slides, discussing, completing assignments using worksheets and presenting their work and responding to each other. The second meeting, in groups students studied worksheets, asked questions, and chose topics, developed topics into exposition text frameworks, and wrote exposition texts in accordance with the structure, and language rules with responsibility. The third meeting, individually students answered questions from teachers regarding exposition text knowledge with honesty and responsibility, choosing topics, developing selected topics into exposition text frameworks, writing exposition texts based on frameworks that had been prepared in 
accordance with the topic, examining their writings individually. They present their work and provide responses.

The social system developed during learning is to maximize cooperation and cooperative interaction between students. They work together to share ideas, discussions, not rely on teachers. Fun class atmosphere. involves personal and interpersonal intelligence. Educators act as motivators, mediators, facilitators. Learning is supported by adequate learning resources, such as books containing exposition texts, magazines, language journals, laptops and projectors to broadcast audio-visual media and a board of appreciation for students' work.

The instructional impact achieved is that those with different learning styles are skilled at writing exposition texts containing conservation values, while the accompanying effects are positive habits in learning, such as cooperating, respecting the opinions of others, developing knowledge in the academic field. The students in this experiment consisted of 29 visual learning styles, 27 audio learning styles, and 20 kinesthetic learning styles. So, students with visual learning style are more dominant.

Initial test results, students get the highest score of 89 and the lowest score of 63 with an average score of 75.04. Assessment aspects, including the suitability of the text content with the topic, the completeness of the exposition text structure, diction, use of sentences, spelling and punctuation. The difference in obtaining pretest and posttest scores is presented in table 1.

Table 1. Average Pretest Score and Posttest Skills for Writing Exposition Text

\begin{tabular}{|l|c|c|c|c|c|c|}
\hline \multirow{2}{*}{ Pengujian } & \multicolumn{6}{|c}{ Skor } \\
\cline { 2 - 7 } & \multicolumn{2}{|c|}{ Tertinggi } & \multicolumn{2}{c|}{ Terendah } \\
\cline { 2 - 7 } & V & A & K & V & A & K \\
\hline Pretest & 90 & 85 & 85 & 60 & 50 & 55 \\
\hline Posttest & 100 & 97 & 84 & 75 & 75 & 75 \\
\hline \multicolumn{9}{|c|}{ Rata-rata } \\
\hline \multicolumn{9}{|c|}{ Pretest } & \multicolumn{5}{c|}{ Posttest } \\
\hline V & A & K & V & A & K \\
\hline 70,83 & 69,09 & 77,69 & 88,12 & 83,15 & 78,21 \\
\hline
\end{tabular}

The highest pretest scores were obtained by students in visual learning style 90 , auditory and kinesthetic learning styles 85 , while the lowest scores were obtained which were visual learning styles 60 , auditory learning styles 50 , and kinesthetic learning styles 55 . The average pretest scores of students in visual learning style 70.83 while students learn audio style

69.09, and the kinesthetic learning style is 77.69. So, the average pretest score of students in the visual, audio, and kinesthetic learning styles is below the minimum completeness criteria.

The highest posttest score was obtained by students with visual learning style of 100 , while the lowest score for students with visual learning style was 75 . The highest score of students with audio learning style was 97 and the lowest was 75 . The highest score of students with kinesthetic learning style 84 and the lowest 75. the average final score of visual-style students was 88.12 and the lowest was 83.15. So, the mean score of students learning visual, audio, and kinetic styles in the final test has reached the Minimum Completeness Criteria, 75.

The completeness of the students' visual learning style was tested using a one-party test (right side) with the hypothesis Ho: $\mathrm{x}^{-}<75$ or H1: $x>75$ through SPSS, so Ho was rejected if $\mathrm{t}$ count $>\mathrm{t}$ table .. Based on the test results obtained tcount of 7.495 and the table is obtained by $\mathrm{df}=29$, sig $5 \%(1$ tailed $)=$

1.699. Because thitung $>\mathrm{t}$ table (7.495> 1.699), Ho is rejected and accepts H1. That is, exposition text writing skills containing the conservation value of students in a visual learning style are more effective.

Learning to write exposition texts containing conservation values with the CIRC model is effective for students from both state and private Madrasah Aliyah. The average score of the attitude of students as a whole before being treated 74 and after treatment 84.26. Changes in positive attitudes in learning using the CIRC model are students more responsible, honest, democratic, creative, and polite. This is consistent with the opinion of Gordon (2014) and (Primary, Pratiwi, \& Andajani, 2016), that learning with the CIRC model familiarizes students in working in groups, responsible for tasks, creative, and democratic because they are involved in a series of joint activities with clear learning goals.

Teams are stages of the CIRC models. Students are accustomed to have a responsible and democratic attitude in heterogeneous groups. Students are very enthusiastic and enjoy learning. They are more creative and democratic towards their friends (Zulaeha, 2013; Aggarwal, 2017). Students are 
accustomed to being responsible for discussing their learning outcomes.

The mean score of writing exposition text obtained by students with visual learning style 88.21, audio learning style 83.26 and kinesthetic

78.35. So, learning to write exposition text containing conservation values with the CIRC model is more effective for students in a visual learning style than auditory and kinesthetic. This happens because the collaboration teams are coordinated with reading group learning, so that it fulfills other goals such as reading comprehension, vocabulary, reading messages, and spelling. Students are motivated to work together in a team (Slavin 2010: 201; Harbaugh, 2010).

\section{Conclusion}

Learning to write exposition text containing conservation values with the CIRC model based on students' learning styles is effective, especially for students with visual learning style based on the average score before and after being treated with the CIRC model. Before being treated, the mean score of exposition text writing skills of students with visual learning style was 70.83 , while after being given treatment 88.12 ; students learning audio style 69.09, while after being given treatment 83.15; kinesthetic learning style students 77.69, while after treatment 78.21. Their behavior shows positive change. This can be seen from the average attitude aspect score before treatment 74.13 to 84.26 after being treated. So, learning to write exposition text in writing with the CIRC model is effective for students to learn visually.

\section{References}

Aggarwal, V. \& Sachar, G. "A Study of Creativity in Relation to Personality types among Secondary School Students". International Journal of Innovative Research \& Development, 5(14), 126-129.

Arikunto, S. (2010). Prosedur Penelitian Sutu Pendekatan Praktik. Jakarta: Rineka Cipta.

Finoza, L. (2009). Komposisi Bahasa Indonesia. Jakarta: Diksi Insan Mulia.

Gordon, R. (2014). "The Social Value of Culture: Learning from
Revolutionary Cuba". European Journal of Social Psychology, 20(1), 95-117.

Harbaugh, ER (2010). "The Effect of Personality Styles (Level of Introversionextroversion) on Social Media Use". The Elon Journal of Undergraduate Research in Communications, 1(2), 70-86.

Kosasih, Engkos. (2012). The Basics of Writing Skills. Bandung: Rama Widya.

Mahsun, MS. (2014). The Text-Based Learning. Jakarta: Rineka Reserved.

Primary, FY, Pratiwi, Y., \& Andajani, K. (2016). "Development of Teaching Materials Writing Love Text Exposition Environment Charged with Modeling Strategies for Learners Class VII SMP" Journal of Education: Theory, Research, and Pengembangan, 1(3), 448-462.

Slavin, RE (2010). Cooperative Learning Theory, Research and Practice. Bandung: Nusa Media.

Sugiyono. (2011). Qualitative and Quantitative Research Methods R \& D. Bandung: Alfabeta.

UNNES Conservation Development Team. (2014). Conservation Education. Semarang: Magnum Main Library in cooperation with the MKU UNNES.

Zulaeha, Ida. (2013). "Innovation Models of Indonesian Learning in Multicultural Society" Journal of Procedia-Social and Behavioral Sciences, 103(2013), 506514.

Zulaeha, Ida. (2016). Theories, Models and Implementation of Learning Creative Writing. Semarang: UNNES Press.

Zulaeha, Ida. (2017). "Effectiveness of Learning Writing Text exposition Conservation Charged with CIRC and TTW Model Based on Learning Styles of Students Class X" Research Report. Semarang: Faculty of Language and Art, State University of Semarang.

Hidayati, N., \& Zulaeha, I. (2018). "The Effectiveness of Poetry Reading Learning using Draladater Model on Extrovert and Introvert Senior High School Students". Seloka: Jurnal Pendidikan Bahasa Dan Sastra Indonesia, 7(1), 1-8. 